\section{Estimation of above-ground biomass and sequestered carbon of Taurus Cedar (Cedrus libani L.) in Antalya, Turkey}

\author{
Birsen Durkaya $^{(1)}$, Ali Durkaya $^{(1)}$, Ender Makineci $^{(2)}$, Mustafa Ülküdür $^{(3)}$
}

Based on data obtained from 36 sample trees, above-ground biomass development of Taurus Cedar was modeled according to tree components on a singletree basis. Carbon concentrations of tree components were established with the help of samples taken from sample trees. The biomass and sequestered carbon were modeled from the standing stem volume of single trees. It was determined that a coefficient of 0.51 could be used for Taurus Cedar species as a conversion factor from fresh weight to dry weight. Carbon concentrations were found to be lowest in branch barks, with a ratio of $49.5 \%$, and highest in needles, with a ratio of $52.8 \%$. According to the results of a comparison between volume, biomass and stored carbon amounts, 70.27 tons of biomass and 35.56 tons of carbon are stored in each standing stem volume of $100 \mathrm{~m}^{3}$.

Keywords: Above-ground Biomass, Carbon Concentration, Carbon Storage, Cedrus libani L., Stem Volume

\section{Introduction}

The use of fossil fuels has determined an increase in the $\mathrm{CO}_{2}$ concentration of the atmosphere, causing the global greenhouse effect. According to the United Nations Framework Convention on Climate Change (UNFCCC) and its Kyoto Protocol (KP), forest ecosystems may contribute toward reducing human-induced greenhouse effect (UNFCCC 2001).

It is well-known that any increase in the level of atmospheric carbon dioxide and other greenhouse gases also increases atmospheric temperature. Carbon dioxide is the most greenhouse gas with the greatest effect, and the steady increase in the amount of carbon dioxide in the atmosphere may be attributed to the use of fossil fuels and deforestation throughout the world (Nowak \& Crane 2002).

Forest ecosystems play a critical role in reducing the greenhouse effect and stabilizing climate by storing atmospheric carbon dioxide as biomass (Dixon et al. 1994, Binkley et al. 2004, Mohanraj et al. 2011).
In order to understand the carbon sequestration process and carbon cycle, it is necessary to obtain data on tree biomass. On the other hand, because carbon is becoming a valued product on the global market, estimating the amount of carbon stored in growing trees and harvested wood is also important (McKinley et al. 2011). The determination of tree biomass is a challenging, time-consuming and costly process due to operations such as the cutting, uprooting, drying, and weighing of tree matter. Alternative techniques have been developed for the estimation of biomass from easily measured tree characteristics. Within the literature, the estimation of biomass values has generally used allometric equations. Allometry is the relationship between above-ground biomass and diameter at breast height and/or total height, below-ground biomass and diameter at breast height and/or total height, and above-ground biomass and below-ground biomass (Specht \& West 2003, Gower et al. 1999). In former studies, scientists have frequently used allometric models for assessing

(1) Bartin University, Faculty of Forestry, 74100 Bartin (Turkey); (2) Istanbul University, Faculty of Forestry, 34473 Bahçeköy-Istanbul (Turkey); (3) Regional Forestry Directorate, 07000 Antalya (Turkey)

@ Birsen Durkaya (bdurkaya@bartin.edu.tr)

Received: Nov 16, 2012 - Accepted: Mar 19, 2013

Citation: Durkaya B, Durkaya A, Makineci E, Ülküdür M, 2013. Estimation of above-ground biomass and sequestered carbon of Taurus Cedar (Cedrus libani L.) in Antalya, Turkey. iForest 6: 278-284 [online 2013-07-01] URL: http://www.sisef.it/iforest/contents/? id=ifor0899-006

Communicated by: Elena Paoletti

above-ground and below-ground biomass (Overman et al. 1994, Sierra et al. 2007, Basuki et al. 2009, Khan \& Faruque 2010, Razakamanarivo et al. 2011, Singh et al. 2011, Alvarez et al. 2012, Lima et al. 2012). Correspondingly, recent studies in Turkey have used allometric relationships to estimate the above-ground biomass for common tree species (Durkaya et al. 2009, 2010a, 2010b). These studies allow the estimation of above-ground biomass according to stem, branch, and leaf components; however, without additional evaluations, such techniques do not enable the estimation of the amount of bark and above-ground biomass, which are commercially valuable and thus removed from the forest during harvest, as well as those with no commercial value, that are left in the forest. Furthermore, there are a limited number of studies on the carbon contents of tree components that may be used for the estimation of the carbon storage capacity of forest ecosystems in Turkey.

This study focuses on Taurus Cedar, a native species of Turkey spread along the Taurus Mountains between the elevations of 800 and $2100 \mathrm{~m}$ (Günay 1990, Boydak 1986). In Turkey, a total of 99325 hectares of pure Taurus Cedar stands exist, 67850 of these hectares are productive and 31475 are unproductive (Yilmaz \& Gürses 1997).

This study examined the following: (1) the determination of the commercially valuable above-ground biomass that has been removed from the forest during harvest as well as that with no commercial value, which has been left; (2) the determination of the carbon content of above-ground tree components; and (3) the development of appropriate models for the conversion of standing stem volume to biomass and stored carbon values of above-ground tree components.

\section{Materials and Methods}

\section{Study area}

Sample trees were randomly selected in pure stands of Taurus Cedar located within the boundaries of the Department of Forestry of Elmali (Antalya) $\left(29^{\circ} 56^{\prime}-30^{\circ} 04^{\prime}\right.$ E - $36^{\circ}$ $\left.33^{\prime}-36^{\circ} 36^{\prime} \mathrm{N}\right)$, where Taurus Cedars grow very successfully. Although this species spreads across the Taurus mountains, its expansion outside the Antalya region is partial and only in small areas. The best growing area and widest expansion of Taurus Cedar is in the Antalya region. In addition, Taurus Cedar is a very valuable species, and permission for tree cutting is generally very hard to obtain. Therefore, data was collected from Elmali (Antalya) district and primarily reflects the state of trees growing on that region. A typical Mediterranean climate prevails in the area of this study: summers are hot and dry, and winters are warm with high 


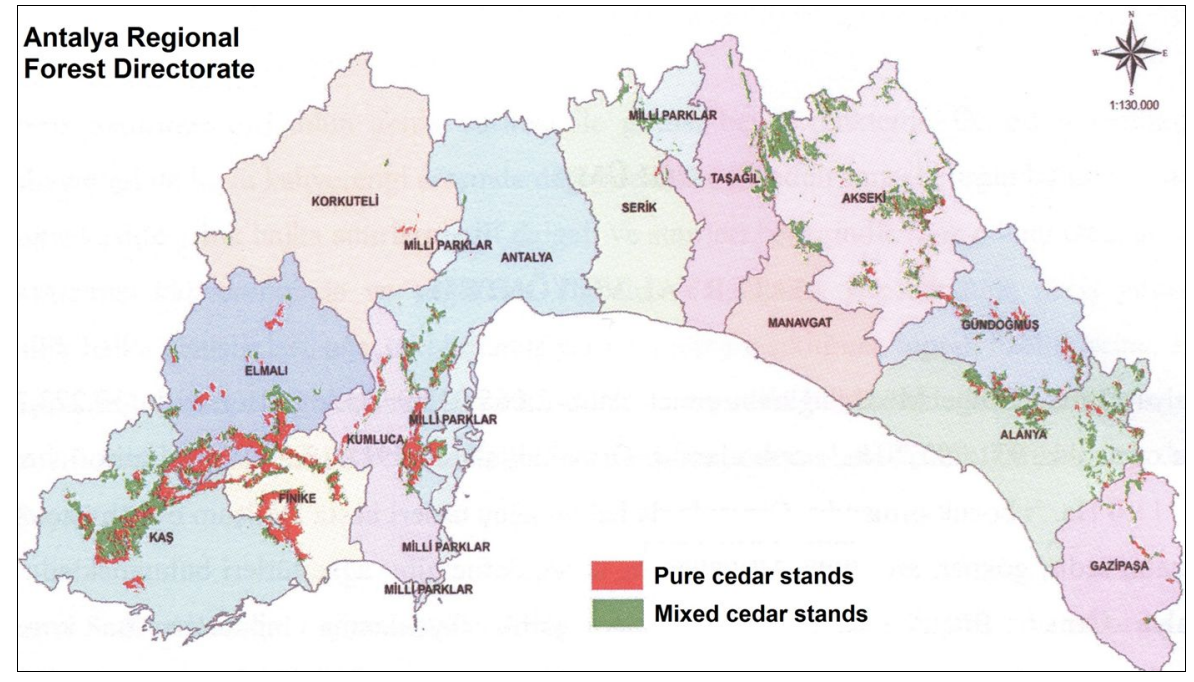

Fig. 1 - Taurus Cedar distribution in Turkey and Antalya Regional Forest Directorate.

rainfall. According to meteorological data, and average relative humidity is $55.25 \%$. the annual average temperature is $12.9{ }^{\circ} \mathrm{C}$, The elevation of the sampling sites was average annual precipitation is $428.4 \mathrm{~mm}$, within the range of 1400 to $1770 \mathrm{~m}$, and

Tab. 1 - Some characteristics of the trees sampled in this investigation.

\begin{tabular}{|c|c|c|c|c|c|}
\hline $\begin{array}{c}\text { Sample } \\
\text { no }\end{array}$ & $\begin{array}{l}\text { DBH } \\
\text { (cm) }\end{array}$ & $\begin{array}{c}\text { Height } \\
\text { (m) }\end{array}$ & $\begin{array}{l}\text { Site } \\
\text { class }\end{array}$ & $\begin{array}{c}\text { Altitude } \\
\text { (m) }\end{array}$ & Exposure \\
\hline 1 & 16 & 12.7 & 3 & 1650 & SW \\
\hline 2 & 29 & 17.7 & 3 & 1470 & $\mathrm{~N}$ \\
\hline 3 & 20 & 12.2 & 3 & 1518 & $\mathrm{~N}$ \\
\hline 4 & 14 & 8.85 & 3 & 1645 & W \\
\hline 5 & 12 & 8.79 & 3 & 1580 & W \\
\hline 6 & 43 & 20.65 & 2 & 1450 & NW \\
\hline 7 & 33 & 19.23 & 2 & 1473 & $\mathrm{~N}$ \\
\hline 8 & 26 & 14.48 & 3 & 1490 & W \\
\hline 9 & 17 & 10.15 & 3 & 1470 & $\mathrm{~N}$ \\
\hline 10 & 8 & 6.52 & 3 & 1408 & $\mathrm{NE}$ \\
\hline 11 & 13 & 9.66 & 3 & 1540 & NW \\
\hline 12 & 11 & 9.02 & 3 & 1550 & $\mathrm{~N}$ \\
\hline 13 & 18 & 9.05 & 3 & 1640 & NW \\
\hline 14 & 20 & 14.2 & 3 & 1526 & $\mathrm{~N}$ \\
\hline 15 & 19 & 12.95 & 3 & 1510 & $\mathrm{NE}$ \\
\hline 16 & 21 & 12.15 & 3 & 1512 & $\mathrm{~N}$ \\
\hline 17 & 30 & 17.38 & 3 & 1548 & NE \\
\hline 18 & 23 & 18.23 & 3 & 1602 & $\mathrm{~N}$ \\
\hline 19 & 32 & 19.6 & 2 & 1430 & NW \\
\hline 20 & 9 & 8.05 & 3 & 1416 & $\mathrm{~N}$ \\
\hline 21 & 10 & 9.92 & 3 & 1425 & $\mathrm{~N}$ \\
\hline 22 & 15 & 12.35 & 3 & 1730 & SW \\
\hline 23 & 24 & 13.81 & 3 & 1547 & NW \\
\hline 24 & 25 & 15.33 & 3 & 1510 & NW \\
\hline 25 & 28 & 15.96 & 3 & 1590 & NW \\
\hline 26 & 22 & 13.95 & 3 & 1500 & NW \\
\hline 27 & 19 & 12.49 & 3 & 1490 & E \\
\hline 28 & 22 & 13.54 & 3 & 1770 & $\mathrm{~W}$ \\
\hline 29 & 20 & 11.85 & 3 & 1680 & $\mathrm{~N}$ \\
\hline 30 & 16 & 10.57 & 3 & 1720 & $\mathrm{~N}$ \\
\hline 31 & 32 & 17.42 & 3 & 1405 & $\mathrm{~N}$ \\
\hline 32 & 23 & 14.25 & 3 & 1388 & $\mathrm{~N}$ \\
\hline 33 & 14 & 10.54 & 3 & 1680 & NW \\
\hline 34 & 18 & 11.45 & 3 & 1497 & E \\
\hline 35 & 9 & 8.9 & 3 & 1424 & SW \\
\hline 36 & 37 & 18.3 & 2 & 1479 & $\mathrm{~N}$ \\
\hline
\end{tabular}

slopes varied between $10 \%$ and $45 \%$. Sampling sites were largely within site class III and partially within site class II.

Taurus Cedar distribution in Turkey and Antalya Regional Forest Directorate are shown in Fig. 1.

\section{Experimental data}

Single trees from pure Taurus Cedar stands in different development phases were analyzed in order to determine above-ground biomass development. A total of 36 sample trees were measured in various diameter and height groups. Some characteristics of sample trees are shown in Tab. 1. As forest stands in Turkey are defined according to tree species, diameter and canopy closure, the principle for determining the biomass development as a function of diameter or of diameter and tree height, rather than age function, was adopted in order to provide a practical means of assessing biomass and energy potential.

Each sample tree was selected at random from those that had no damage, and cut very close to soil level after cleaning the surrounding area. The entire length of cut trees and the diameter at breast height (to the nearest $\mathrm{mm}$ and bidirectional) were measured. The branches of the cut sample trees were then removed from the stem, weighed and grouped as follows: (a) thinner than 4 $\mathrm{cm}$ (non-commercial); (b) thicker than $4 \mathrm{~cm}$ (with commercial value). Branch samples at average thickness were taken from branch groups thinner than $4 \mathrm{~cm}$ and thicker than 4 $\mathrm{cm}$. In addition, needle samples were taken with shoots. The stem was divided into 2.05$\mathrm{m}$ sections, and the diameters of sections at both ends and the root collar diameter and height of the end piece were measured to determine the stem volume by using Smalian's formula. Each stem section was weighted, and 5-cm-thick stem samples were taken from the middle of these sections. All samples were then labeled and preserved in plastic bags.

Stem, branch and needle samples were brought to the laboratory; needles were separated from the shoots; bark was separated from the wood; and fresh weights were determined. Samples were first air-dried, then oven-dried at $65 \pm 3{ }^{\circ} \mathrm{C}$ until the weight stabilized, and the final dry weights were determined.

\section{Modeling the above-ground biomass} values

The biomass of tree components, such as the stem, branches, leaves, bark, coarse root and fine root, were generally estimated using different allometric regression models, based on DBH or DBH-H (Alberti et al. 2005, Guidi et al. 2008, Miksys et al. 2007, Peichl \& Arain 2007, Soares \& Schaeffer-Novelli 2005, Somogyi et al. 2008, Zewdie et al. 
2009). The present study tested differen models in determining biomass as a function of DBH or DBH and H. Appropriate functions were chosen and used in the estimation of biomass.

\section{Measuring carbon concentrations}

The composition of vegetation carbon $(\mathrm{C})$ is found by applying a carbon conversion factor to dry weight (Gower et al. 2001). According to previous studies, the value of this factor varies between 43.7 and $55.7 \%$, and a deviation of $10 \%$ may occur in calculations (Laiho \& Laine 1997, Elias \& Potvin 2003 Lamlom \& Savidge 2003, Bert \& Danjon 2006, Zhang et al. 2009). As the size of deviation may be large, it would be beneficial to reduce the uncertainties in the calculation of biomass carbon components. In calculating the carbon cycle of forest ecosystems in Turkey, generally accepted factors for the conversion of biomass to carbon were used. As these factors may show a considerable degree of variation, the determination of carbon concentrations of tree components for common tree species is of utmost importance.

Dried samples were first weighed, then divided into small pieces, and converted into powder as appropriate for carbon analysis. Samples were dried again in order to prevent the effect of moisture, and carbon contents were determined via a $\mathrm{CN}$ analyzer as the amount of C for a dry weight of $100 \mathrm{~g}(\%)$.

\section{Checking the compliance of models}

During the determination of the most appropriate functions, five different compliance measures were utilized. Calculations were made by using MS Excel. These measures were as follows: coefficient of determination $\left(R^{2}\right)$, standard error of estimate $(S E)$, total error $[T E(\%)]$, mean deviation $(\bar{D})$, and absolute mean deviation $(|\bar{D}|)$. Average difference, average absolute difference, standard error, total error and average absolute error values should be small and the coefficient of determination value should be large in order to obtain a reliable model; however, a function that provides reliable results according to one or more of these values may give inconsistent results according to other variables. In such situations, a "success range", comprising all of the measured values, should be prepared in place of comparing biomass functions according to measure values (Reed \& Gren 1984). All of these measures were taken into consideration in the selection of appropriate models in this study.

\section{Results}

To determine single-tree aboveground biomass amounts, the most suitable allometric models were chosen in accordance with compliance measures. These models are given in Tab. 2.

\section{Above-ground biomass equations}

The models using the diameter at breast height $\left(d_{1.30}\right)$ as an independent variable were tested, and those providing the best goodness-of-fit were determined based on their compliance statistics. Within the biomass equations, the following units of measurement were used: oven-dry weight $(\mathrm{kg})$; diameter at breast height $(d, \mathrm{~cm})$; and tree height $(h, \mathrm{~m})$. The best fitting models obtained (eqns. 1 to 10) are shown in Tab. 2.

The models that use diameter at breast height $\left(d_{1.30}\right)$ and tree height $(h)$ as independent variables were tested, and those showing the best goodness-of-fit were determinined nased on their fit statistics (eqns. 11 to 20 - Tab. 3).

\section{Single entry volume equations}

For forestry practice in Turkey, stands within a forest ecosystem are classified according to tree species, diameter class, and canopy closure. Standing stock is expressed as barked stem volume. In the determination of how much $\mathrm{C}$ is sequestered in particular stands, biomass values of single tree components are first computed by biomass mo- dels for the related tree species, using median stand diameter values or median stand diameter - median stand height values. The resultant value is multiplied by the number of trees per hectare, and thus the total biomass of the stand is found. Such procedures generally complicate the calculation process. The process may be facilitated considerably by the estimation of stand biomass from standing stem volumes.

In order to model the relationship between standing stem volume and biomass and carbon storage capacities, a volume equation is required. For forestry practice in Turkey, standing stem volumes are determined according to diameter at breast height. Therefore, the function of volume was determined on the basis of diameter at breast height. For this purpose, various models were checked according to compliance criteria, and the following model was adopted:

$$
V=0.0676+\left(-0.0134 d_{1.30}\right)+\left(0.001 d_{1.30}^{2}\right)
$$

$\left(\mathrm{R}^{2}=0.977\right)$ where $V$ is the stem volume $\left(\mathrm{m}^{3}\right)$ and $d_{1.30}$ is the diameter at breast height (cm)

\section{Carbon concentrations of tree compo- nents}

Determining the carbon content of tree components was achieved using samples from 36 sample trees. To produce usable carbon determination samples, dried samples of all tree components from 36 sample trees were divided into small pieces and then converted into powder as appropriate for carbon analysis.

Carbon contents were determined via a $\mathrm{CN}$ analyzer as the amount of $\mathrm{C}(\%)$ for a dry weight of $100 \mathrm{~g}$. Carbon contents of components are shown in Tab. 4, as minimum, maximum and mean values.

\section{Relationships between standing stem volume and biomass}

Various models were tested in order to en-

Tab. 2 - Best-fitting models and their fitting statistics obtained using the diameter at breast height $\left(d_{1.30}\right)$ as predictor variable. (S): stem biomass; (SB): stem bark biomass; (CB): commercial branch biomass; (CBB): commercial branch bark biomass; (NB): non-commercial branch biomass; (NBB): non-commercial branch bark biomass; (T): twig biomass; (N): needle biomass; (TC): total crown biomass; (WT): whole tree biomass.

\begin{tabular}{|c|c|c|c|c|c|c|c|}
\hline Single-Tree Biomass Equations & $\mathbf{R}^{2}$ & $\mathbf{F}$ & SE & TE (\%) & $\overline{\mathbf{D}}$ & $|\overline{\mathbf{D}}|$ & eqn. \\
\hline $\mathrm{S}=-31.0516+\left(0.303619 \cdot d_{1.30}{ }^{2}\right)$ & 0.93 & 430 & 34 & 0.00022 & 0.00027 & 27.57 & 1 \\
\hline $\mathrm{SB}=-0.71530+\left(0.056879 \cdot d_{1.30^{2}}\right)$ & 0.9 & 312 & 7.5 & -0.000095 & -0.000027 & 5.15 & 2 \\
\hline $\mathrm{CB}=-34.7618+\left(1.974415 \cdot d_{1.30}\right)$ & 0.81 & 78 & 6.6 & -0.00013 & -0.000022 & 4.81 & 3 \\
\hline $\mathrm{CBB}=-14.5495+\left(0.828923 \cdot d_{1.30}\right)$ & 0.84 & 95 & 2.5 & 0.00018 & 0.000013 & 1.87 & 4 \\
\hline $\mathrm{NB}=9.692722+\left(-1.1675 \cdot d_{1.30}\right)+\left(0.046302 \cdot d_{1.30}{ }^{2}\right)$ & 0.88 & 119 & 3.5 & 0.00157 & 0.000139 & 2.54 & 5 \\
\hline $\mathrm{NBB}=9.999136+\left(-1.22839 \cdot d_{1.30}\right)+\left(0.041916 \cdot d_{1.30}{ }^{2}\right)$ & 0.88 & 116 & 2.7 & -0.407 & -0.0234 & 1.92 & 6 \\
\hline $\mathrm{T}=-0.27283+\left(0.013135 \cdot d_{1.30}^{2}\right)$ & 0.83 & 163 & 2.4 & -0.0035 & -0.00024 & 1.47 & 7 \\
\hline $\mathrm{N}=0.817584+\left(0.019014 \cdot d_{1.30}{ }^{2}\right)$ & 0.84 & 177 & 3.4 & 0.00218 & 0.000229 & 2.36 & 8 \\
\hline $\mathrm{TC}=20.73819+\left(-3.36526 \cdot d_{1.30}\right)+\left(0.186172 \cdot d_{1.30}{ }^{2}\right)$ & 0.95 & 340 & 10 & -0.00017 & -0.000075 & 6.8 & 9 \\
\hline $\mathrm{WT}=37.21449+\left(-8.08322 \cdot d_{1.30}\right)+\left(0.644812 \cdot d_{1.30}{ }^{2}\right)$ & 0.96 & 360 & 42 & 0.00007 & 0.000138 & 27 & 10 \\
\hline
\end{tabular}


Tab. 3 - Best-fitting models and their fitting statistics obtained using the diameter at breast height $\left(d_{1.30}\right)$ and tree height $(h)$ as predictors. Labels are as in Tab. 2 .

\begin{tabular}{|c|c|c|c|c|c|c|c|}
\hline Single-Tree Biomass Equations & $\mathbf{R}^{2}$ & $\mathbf{F}$ & SE & TE (\%) & $\overline{\mathbf{D}}$ & $|\overline{\mathbf{D}}|$ & eqn. \\
\hline $\begin{aligned} \mathrm{S}= & 18.18743+\left(-8.10728 \cdot d_{1.30}\right)+(0.06557 \cdot h) \\
& +\left(0.3364 \cdot d_{1.30}{ }^{2}\right)+\left(0.571319 \cdot h^{2}\right)\end{aligned}$ & 0.95 & 148 & 29.5 & 0.00006 & 0.00007 & 17.6 & 11 \\
\hline $\begin{aligned} \mathrm{SB}= & 8.265324+\left(-0.33769 \cdot d_{1.30}\right)+(-1.90362 \cdot h) \\
& +\left(0.036965 \cdot d_{1.30}{ }^{2}\right)+\left(0.18222 \cdot h^{2}\right)\end{aligned}$ & 0.93 & 93 & 6.9 & -0.00013 & -0.00004 & 4.3 & 12 \\
\hline $\begin{aligned} \mathrm{CB}= & 236.1674+\left(-19.7481 \cdot d_{1.30}\right)+\left(1.348633 \cdot d_{1.30} \cdot h\right) \\
& +\left(0.389027 \cdot d_{1.30}\right)+(-16.9361 \cdot h) \\
& +\left(-0.02394 \cdot d_{1.30}{ }^{2}\right)\end{aligned}$ & 0.91 & 29 & 5 & -0.34 & -0.05 & 3.1 & 13 \\
\hline $\begin{aligned} \mathrm{CBB}= & 106.0697+\left(-9.62108 \cdot d_{1.30}\right)+\left(0.578656 \cdot d_{1.30} \cdot h\right) \\
& +\left(0.216057 \cdot d_{1.30}{ }^{2}\right)+(-6.80524 \cdot h) \\
& +\left(-0.01174 \cdot d_{1.30}{ }^{2} h\right)\end{aligned}$ & 0.93 & 36 & 1.9 & -0.36 & -0.025 & 1.2 & 14 \\
\hline $\begin{aligned} \mathrm{NB}= & -26.5548+\left(1.808129 \cdot d_{1.30}\right)+\left(-0.283 \cdot d_{1.30} \cdot h\right) \\
& +\left(-0.00297 \cdot d_{1.30}{ }^{2}\right)+(3.55587 \cdot h) \\
& +\left(0.00478 \cdot d_{1.30}{ }^{2} h\right)\end{aligned}$ & 0.92 & 66 & 3 & 0.041 & 0.0036 & 1.9 & 15 \\
\hline $\begin{aligned} \mathrm{NBB}= & -25.8203+\left(2.4104 \cdot d_{1.30}\right)+\left(-0.26829 \cdot d_{1.30} \cdot h\right) \\
& +\left(-0.04056 \cdot d_{1.30}^{2}\right)+(2.880058 \cdot h) \\
& +\left(0.00566 \cdot d_{1.30}^{2} \cdot h^{2}\right)\end{aligned}$ & 0.94 & 92.8 & 1.98 & -0.0117 & -0.00066 & 1.37 & 16 \\
\hline $\begin{aligned} \mathrm{T}= & 1.05288+\left(-0.20535 \cdot d_{1.30}\right)+(-0.00673 \cdot h) \\
& +\left(0.013945 \cdot d_{1.30}^{2}\right)+\left(0.014775 \cdot h^{2}\right)\end{aligned}$ & 0.84 & 39 & 2.5 & 0.0049 & 0.00032 & 1.5 & 17 \\
\hline $\begin{aligned} \mathrm{N}= & -11.6569+\left(2.584704 \cdot d_{1.30}\right)+\left(-0.07867 \cdot d_{1.30} \cdot h^{2}\right) \\
& +\left(-0.08286 \cdot d_{1.30}^{2}\right)+\left(0.004274 \cdot d_{1.30}^{2} \cdot h\right)\end{aligned}$ & 0.86 & 49 & 3.2 & 0.0113 & 0.0011 & 2.3 & 18 \\
\hline $\begin{aligned} \mathrm{TC}= & 8.978191+\left(-1.4041 \cdot d_{1.30}\right)+\left(0.0333 \cdot d_{1.30} \cdot h\right) \\
& +\left(0.044973 \cdot d_{1.30}^{2}\right)+\left(0.004129 \cdot d_{1.30}^{2} \cdot h\right)\end{aligned}$ & 0.96 & 179 & 10.4 & -0.00587 & -0.00263 & 6.3 & 19 \\
\hline $\begin{aligned} \mathrm{WT}= & 51.38543+\left(-12.2998 \cdot d_{1.30}\right)+(-2.75361 \cdot h) \\
& +\left(0.543984 \cdot d_{1.30}^{2}\right)+\left(0.896138 \cdot h^{2}\right)\end{aligned}$ & 0.97 & 264 & 35.1 & -0.00001 & -0.00002 & 21.1 & 20 \\
\hline
\end{tabular}

Tab. 4 - Carbon concentrations of tree components.

\begin{tabular}{lllc}
\hline Tree components & $\begin{array}{c}\text { Min } \\
\mathbf{( \% )}\end{array}$ & $\begin{array}{c}\text { Max } \\
\mathbf{( \% )}\end{array}$ & $\begin{array}{c}\text { Mean } \\
(\%)\end{array}$ \\
\hline Stem wood & 50.1 & 52 & 50.9 \\
Stem bark & 50 & 52.8 & 51.1 \\
Commercial branch & 50.3 & 53.2 & 50.9 \\
Commercial branch bark & 48 & 50.6 & 49.5 \\
Non-commercial branch & 50 & 51.7 & 50.6 \\
Non-commercial branch bark & 48 & 51.9 & 49.5 \\
Twig & 48.5 & 51.4 & 50.1 \\
Needle & 51.6 & 54.1 & 52.8 \\
\hline
\end{tabular}

able the determination of biomass amounts from standing stem volumes, and those that yielded the best results with regard to their goodness-of-fit were identified. The models (eqns. 21 to 30 ) enabling the determination of biomass amounts from standing stem volumes of single trees and stand basis are given in Tab. 5 along with the compliance criteria for these models.

Relationships between standing stem volume and carbon

For forestry practice in Turkey, it is required that the amount of sequestered carbon to be determined from the standing stem vo-

Tab. 5 - Best-fitting biomass models and their statistics using the standing stem volume $(V)$ as predictor. (S): stem biomass; (SB): stem bark biomass; (CB): commercial branch biomass, (CBB): commercial branch bark biomass; (NB): non-commercial branch biomass; (NBB): noncommercial branch bark biomass; (T): twig biomass; (N): needle biomass; (TC): total crown biomass; (WT): whole tree biomass.

\begin{tabular}{|c|c|c|c|c|c|c|c|}
\hline Single-Tree Biomass Equations & $\mathbf{R}^{2}$ & $\mathbf{F}$ & SE & TE (\%) & $\overline{\mathbf{D}}$ & $|\overline{\mathbf{D}}|$ & eqn. \\
\hline $\mathrm{S}=-1.21525+(439.8813 \cdot V)$ & 0.98 & 1660 & 34 & -0.0000095 & -0.0000067 & 10.1 & 21 \\
\hline $\mathrm{SB}=5.066058+(81.7774 \cdot V)$ & 0.94 & 516 & 33 & -0.0000012 & -0.00000033 & 3.86 & 22 \\
\hline $\mathrm{CB}=-2.04429+(44.42235 \cdot V)$ & 0.78 & 64 & 18 & -0.000023 & -0.0000022 & 2.76 & 23 \\
\hline $\mathrm{CBB}=-0.84186+(18.71417 \cdot V)$ & 0.82 & 80 & 18 & 0.0000471 & 0.0000019 & 1.03 & 24 \\
\hline $\mathrm{NB}=-0.0987+(31.36708 \cdot V)$ & 0.83 & 163 & 33 & 0.000041 & 0.0000035 & 2.28 & 25 \\
\hline $\mathrm{NBB}=-0.96709+(23.2273 \cdot V)$ & 0.77 & 111 & 33 & -0.000018 & -0.000001 & 1.96 & 26 \\
\hline $\mathrm{T}=-1.351584+(17.90588 \cdot V)$ & 0.78 & 117 & 34 & -0.000014 & -0.25 & 1.41 & 27 \\
\hline $\mathrm{N}=3.02316+(26.43525 \cdot V)$ & 0.82 & 152 & 34 & -0.000011 & -0.181 & 2.51 & 28 \\
\hline $\mathrm{TC}=-1.58508+(164.3801 \cdot V)$ & 0.93 & 473 & 34 & -0.000012 & -0.536 & 7.73 & 29 \\
\hline $\mathrm{WT}=1.641103+(686.902 \cdot V)$ & 0.99 & 2558 & 34 & -0.0000025 & -0.0000049 & 13.39 & 30 \\
\hline
\end{tabular}


Tab. 6 - Best-fitting carbon models and their fitting statistics using the standing stem volume $(V)$ as predictor. (S): stem carbon; (SB): stem bark carbon; (CB): commercial branch carbon; (CBB): commercial branch bark carbon; (NB): non-commercial branch carbon; (NBB): noncommercial branch bark carbon; (T): twig carbon, (N): needle carbon; (TC): total crown carbon, (WT): whole tree carbon.

\begin{tabular}{|c|c|c|c|c|c|c|c|}
\hline Single-Tree Carbon Content Equations & $\mathbf{R}^{2}$ & $\mathbf{F}$ & SE & TE (\%) & $\overline{\mathbf{D}}$ & $|\overline{\mathbf{D}}|$ & eqn. \\
\hline $\mathrm{S}=-1.55537+(226.4176 \cdot V)$ & 0.99 & 3219 & 26 & -0.000009 & -0.0000052 & 3.74 & 31 \\
\hline $\mathrm{SB}=2.2043+(44.88568 \cdot V)$ & 0.93 & 322 & 25 & -0.000026 & -0.0000035 & 1.97 & 32 \\
\hline $\mathrm{CB}=-2.48641+(25.50714 \cdot V)$ & 0.87 & 87 & 13 & 0.0000338 & 0.00000137 & 1.02 & 33 \\
\hline $\mathrm{CBB}=-1.0229+(10.99776 \cdot V)$ & 0.87 & 83 & 13 & -0.000097 & -0.0000017 & 0.42 & 34 \\
\hline $\mathrm{NB}=0.739696+(11.8609 \cdot V)$ & 0.76 & 78 & 25 & 0.0000091 & 0.00000033 & 1.059 & 35 \\
\hline $\mathrm{NBB}=0.397799+(7.15052 \cdot V)$ & 0.82 & 110 & 25 & 0.0000134 & 0.00000029 & 0.515 & 36 \\
\hline $\mathrm{T}=1.184463+(5.734686 \cdot V)$ & 0.71 & 64 & 26 & -0.0000028 & -0.00000007 & 0.716 & 37 \\
\hline $\mathrm{N}=2.2186+(10.94115 \cdot V)$ & 0.7 & 60 & 26 & 0.0000049 & 0.00000025 & 1.31 & 38 \\
\hline $\mathrm{TC}=1.282092+(71.20486 \cdot V)$ & 0.92 & 283 & 26 & 0.0000039 & 0.00000074 & 3.35 & 39 \\
\hline $\mathrm{WT}=1.518083+(343.1626 \cdot V)$ & 0.99 & 4136 & 26 & 0.0000023 & 0.00000199 & 4.53 & 40 \\
\hline
\end{tabular}
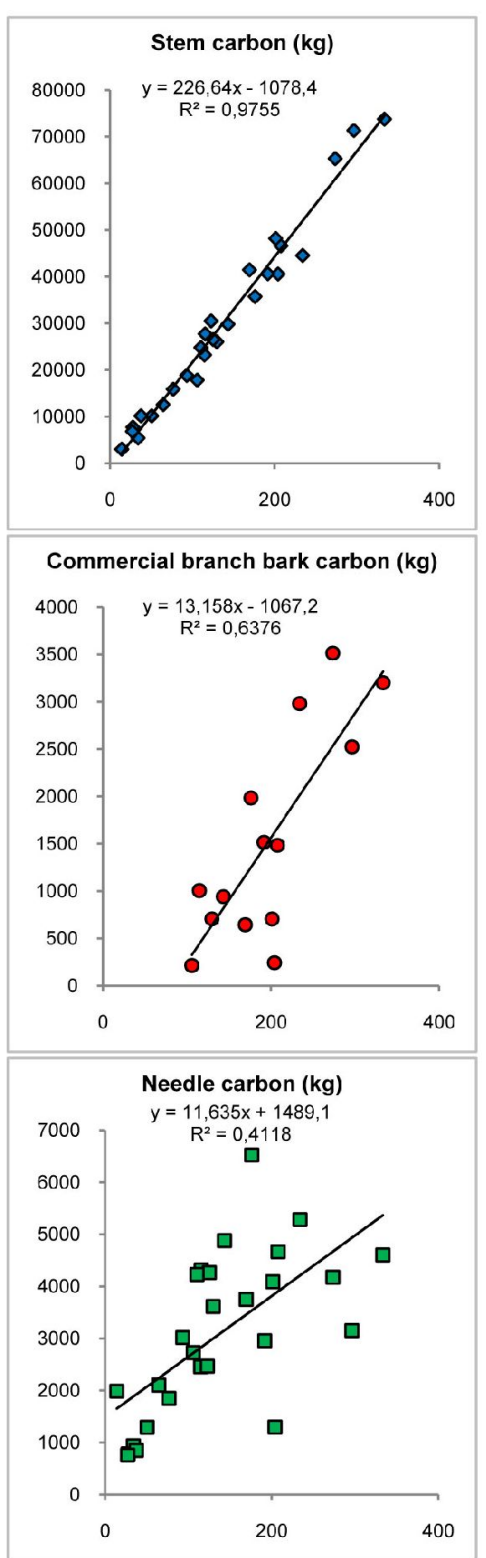

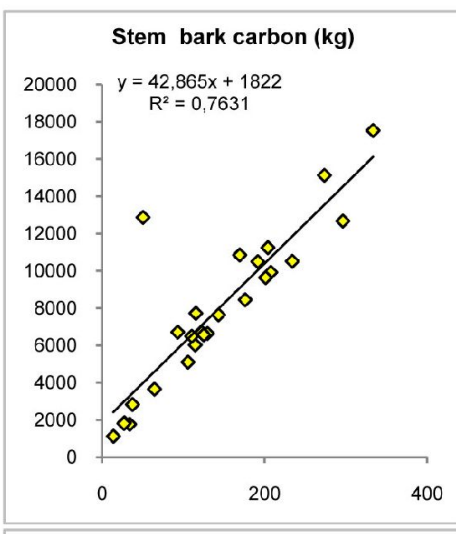

Non-commercial branch carbon $(\mathbf{k g})$

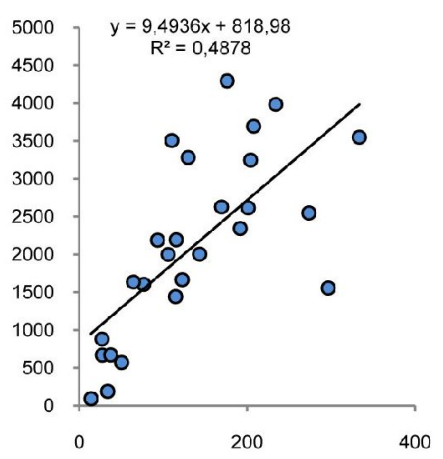

Total crown carbon $(\mathbf{k g})$

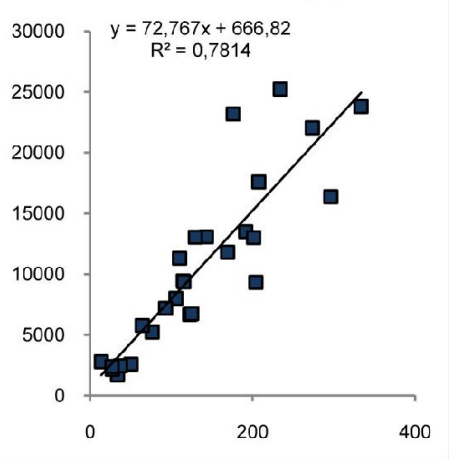

Stem Volume $\left(\mathrm{m}^{3} \mathrm{ha}^{-1}\right)$

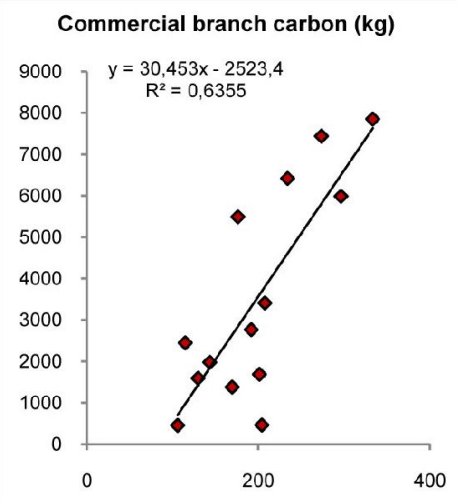

Non-commercial branch bark carbon $(\mathbf{k g})$

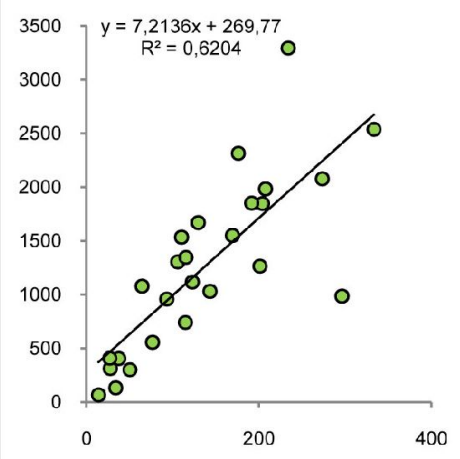

Whole tree carbon $(\mathrm{kg})$

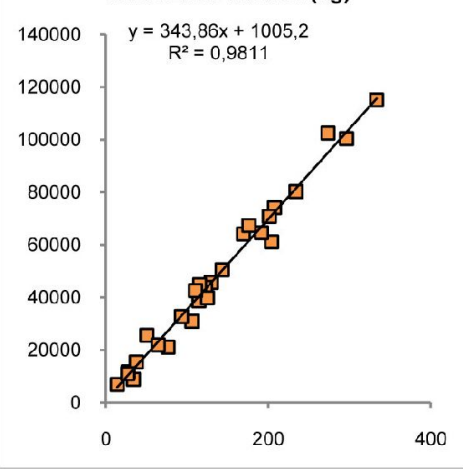

Fig. 2 - Relations between standing stem volume $\left(\mathrm{m}^{3}\right)$ and tree components. 


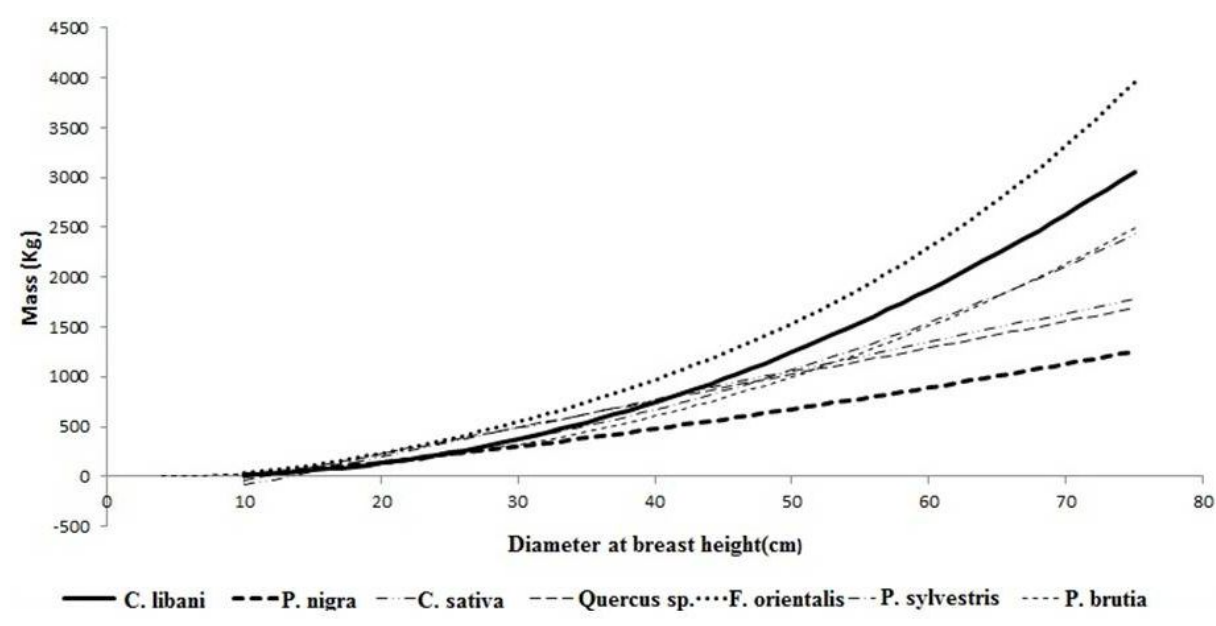

lume. Therefore, models were established that enable the determination of sequestered carbon amounts considering the values of standing stem volume. These models (eqns 31 to 40) and relevant compliance criteria are given in Tab. 6. Relations between standing stem volume and tree components are shown in Fig. 2.

\section{Discussion}

Mass-based carbon concentrations are widely used for the conversion of biomass to the amount of stored carbon. A study by Zhang et al. (2009) found the average amount of carbon in the stem to be $49.9 \% \pm 1.3$ (mean $\pm \mathrm{SE}$ ) for 10 different species, varying between 43.7 and $55.6 \%$ according to species. A study by Lamlom \& Savidge (2003) of 41 species reported this value to be in the range of 46.3 to $55.2 \%$. The generally accepted method is to determine the amount of stored carbon by multiplying the total dry weight of trees by a coefficient of 0.5 (Nowak \& Crane 2002). In the present study, the carbon content of stem wood was found to be an average of $50.9 \%$. Carbon concentrations were found to be lowest in branch barks (49.5\%) and highest in needles $(52.8 \%)$. When carbon concentrations are evaluated as a whole, it can be seen that these values are quite close to the generally accepted level of $50 \%$ (Brown \& Lugo 1982).

McPherson et al. (1994) conducted a literature review on the conversion of fresh biomass to dry biomass and adopted an average coefficient of 0.56 for deciduous trees and 0.48 for coniferous trees. According to the results of the present study, the conversion factor from fresh weight to dry weight for Taurus Cedar was calculated as an average of 0.51 for above-ground components. This coefficient is higher than that predicted for coniferous species.

One of the main aims of the study is to determine the amounts of commercial and noncommercial parts of Taurus Cedar. Non- commercial parts are left to forests and decompose within a few years. Thus, for longterm carbon cycle forecasting, it is also necessary to determine the amount of parts left. According to the study's findings, $15.5 \%$ of a Taurus Cedar tree is left to forest on average. This ratio vary $1 \%$ maximum between young and old trees.

The study also offers a way to estimate the sequestered biomass and carbon amounts by using the standing stem volume variable. The results of the study reveal that 70.27 tons of biomass and 35.56 tons of carbon are stored for $100 \mathrm{~m}^{3}$ of standing stem volume.

The change of total single-tree biomass amounts estimated for some tree species in Turkey according to DBH is seen in Fig. 3. As can be seen, beech has the highest single tree weight value according to $\mathrm{DBH}$, and black pine has the lowest. It is observed that Taurus Cedar has the second highest single tree oven-dried weight compared with scots pine, black pine, beech, oak and chestnut.

\section{Conclusions}

In order to accurately determine the amount of carbon sequestered in forests, it is more appropriate to conduct an individual study of each species, rather than basing calculations on non-specific conversion factors. As seen in the literature, carbon concentrations differ considerably according to various tree species and components.

For forestry practice in Turkey, stands are defined according to tree species, tree diameter class and canopy closure. Tree diameter classes are termed "development ages" and represent a considerably wider range of diameters. Therefore, it is impossible to utilize biomass and carbon models that are based on tree diameter or height alone by only using data in the management plan. Therefore, additional studies are required. The results of the present study make it possible to attain above-ground biomass and sequestered carbon values safely and without any auxiliary operation by using the standing
Fig. 3 - Biomass changes according to diameter at breast height in single trees according to species. stem volume, which is the most practical element in management plans. Using present models, it is also possible to estimate the above-ground biomass, the amount removed from the forest (commercially valuable), and the amount left to the forest (no commercial value).

Within the scope of this study, aboveground modeling was performed, whereas no study of below-ground carbon sequestration capacities was conducted due to lack of study opportunities. If these shortcomings are addressed in future studies, a major knowledge gap will be filled.

\section{References}

Alberti G, Candido P, Peressotti A, Turco S, Piussi P, Zerbi G (2005). Above ground biomass relationships for mixed ash (Fraxinus excelsior L. and Ulmus glabra Hudson) stands in Eastern Prealps of Friuli Venezia Giulia (Italy). Annals of Forest Science 62: 831-836. - doi: 10.1051/forest:2005089

Alvarez E, Duque A, Saldarriaga J, Cabrera K, Salas G, Valle I, Lema A, Moreno F, Orrego S, Rodriguez L (2012). Tree above-ground biomass allometries for carbon stocks estimation in the natural forests of Colombia. Forest Ecology and Management 267: 297-308. - doi: 10.1016/j. foreco.2011.12.013

Basuki TM, van Laake PE, Skidmore AK, Hussin YA (2009). Allometric equations for estimating teh above-ground biomass in tropical lowland Dipterocarp forests. Forest Ecology and Management 257: 1684-1694. - doi: 10.1016/j.foreco. 2009.01.027

Bert D, Danjon F (2006). Carbon concentration variations in the roots, stem and crown of mature Pinus pinaster (Ait.). Forest Ecology and Management 222: 279-295. - doi: 10.1016/j.foreco. 2005.10.030

Binkley D, Stape JL, Ryan MG (2004). Thinking about efficiency of resource use in forests. Forest Ecology and Management 193: 5-16. - doi: 10.1016/j.foreco.2004.01.019

Boydak M (1986). Distribution, ecology, silvicultural characteristics and natural and cultural re- 
generation problems of lebanon (Taurus) Cedar (Cedrus libani A. Rich). Journal of Forest Research Institute, Ankara, Turkey, pp. 7-56.

Brown S, Lugo AE (1982). The storage and production of organic matter in tropical forests and their role in global carbon cycle. Biotropica 14: 161-187. - doi: 10.2307/2388024

Dixon RK, Trexler MC, Wisniewski J, Brown S, Houghton RA, Solomon AM (1994). Carbon pools and flux of global forest ecosystems. Forest Science 263 (3): 185-190. - doi: 10.1126/science.263.5144.185

Durkaya A, Durkaya B, Ünsal A (2009). Predicting the above-ground biomass of calabrian pine (Pinus brutia Ten.) stands in Turkey. African Journal of Biotechnology 8 (11): 2483-2488.

Durkaya A, Durkaya B, Atmaca S (2010a). Predicting the above-ground biomass of Scots Pine (Pinus sylvestris L.) stands in Turkey. Energy Sources 32: 485-493. - doi: 10.1080/15567030 802612473

Durkaya A, Durkaya B, Çakil E (2010b). Predicting the above-ground biomass of crimean pine (Pinus nigra) stands in Turkey. Journal of Environmental Biology 31: 115-118.

Elias M, Potvin C (2003). Assessing inter- and intra-specific variation in trunk carbon concentration for 32 neotropical tree species. Canadian Journal of Forest Research 33: 1039-1045. - doi: 10.1139/x03-018

Gower ST, Kucharik CJ, Norman JM (1999). Direct and indirect estimation of leaf area index, $\mathrm{F}(\mathrm{APAR})$ and net primary production of terrestrial ecosystem. Remote Sensing Environmental 70: 29-51. - doi: 10.1016/S0034-4257(99)00056 $-5$

Gower ST, Krankina O, Olson RJ, Apps M, Linder S, Wang C (2001). Net primary production and carbon allocation patterns of boreal forest ecosystems. Ecological Applications 11:1395-1411. - doi: 10.1890/1051-0761(2001) 011[1395:NPPACA]2.0.CO;2

Guidi W, Piccioni E, Ginanni M, Bonari E (2008). Bark content estimation in poplar (Populus deltoides L.) short-rotation coppice in Central Italy. Biomass Bioenergy 32: 518-524. - doi: 10.1016/j.biombioe.2007.11.012

Günay T (1990). A relic cedar (Cedrus libani A. Rich) stand and its ecologic properties at steppe passing zone in Afyon-Emirdag Upper Çaykisla Valley. Forest Research Institute 59: 53-63.

Hall DO, Rosillo-Calle F, Williams RH, Woods J (1993). Biomass energy supply and prospects. In: "Reneweable Energy: Sources for Fuel and Electricity". Island Press, Washington, DC, USA, pp. 593-651.

Khan MNI, Faruque O (2010). Allometric rela- tionships for predicting the stem volume in a Dalbergia sisso Rogb. plantation in Bangladesh. iForest 3: 153-158. - doi: 10.3832/ifor0554-003

Laiho R, Laine J (1997). Tree stand biomass and carbon content in an age sequence of drained pine mires in southern Finland. Forest Ecology and Management 93: 161-169. - doi: 10.1016/ S0378-1127(96)03916-3

Lamlom SH, Savidge RA (2003). A reassessment of carbon content in wood: variation within and between 41 North American species. Biomass Bioenergy 25: 381-388. - doi: 10.1016/S09619534(03)00033-3

Lima AJN, Suwa R, Ribeiro HPM, Kajimoto T, Santos J, Silva RP, Souza CAS, Barros PC, Noguchi H, Ishizuka M, Higuchi (2012). Allometric models for estimating above- and below-ground biomass in Amazonian forests at São Gabriel da Cachoeira in the upper Rio Negro, Brazil. Forest Ecology and Management 277: 163-172. - doi: 10.1016/j.foreco.2012.04.028

McKinley DC, Ryan MG, Birdsey RA, Giardina CP, HealthLS, Houghton RA, Jackson RB, Morrison JF, Murray $\mathrm{BC}$, Pataki DE, Skog KE (2011). A synthesis of current knowledge on forests and carbon storage in the United States. Ecological Applications 21 (6): 1902-1924. doi: 10.1890/10-0697.1

McPherson EG, Nowak DJ, Rowntree RA (1994). Chicago's urban forest ecosystem: results of the Chicago urban forest climate project. General Technical Report NE-186.6, USDA Forest Service, Radnor, PA, USA, pp. 83-94.

Miksys V, Varnagiryte-Kabasinskiene I, Stupak I, Armolaitis K, Kukkola M, Wojcik J (2007). Above-ground biomass functions for scots pine in Lithuania. Biomass Bioenergy 31: 685-692. doi: 10.1016/j.biombioe.2007.06.013

Mohanraj R, Saravanan J, Dhanakumar S (2011). Carbon stock in Kolli forests, Eastern Ghats (India) with emphasis on above ground biomass, litter, wood debris and soils. iForest 4: 61-65.

Nowak DJ, Crane DE (2002). Carbon storage and sequestration by urban trees in the USA. Environmental Pollution 116: 381-389. - doi: 10. 1016/S0269-7491(01)00214-7

Overman JPM, Witte HJL, Saldarriaga JG (1994). Evaluation of regression for above ground biomass determination in Amazon rain forest. Journal of Tropical Ecology 10: 207-218. - doi: 10.1017/S0266467400007859

Peichl M, Arain MA (2007). Allometry and partitioning of above- and below ground tree biomass in an age-sequence of white pine forests. Forest Ecology and Management 253: 68-80. - doi: 10.1016/j.foreco.2007.07.003

Razakamanarivo R, Razakavolona A, Razafin- drakoto MA, Vieilledent G, Albrecht A (2011). Below-ground biomass production and allometric relationships of eucalyptus coppice plantation in the central highlands of Madagascar. Biomass and Bioenergy 45: 1-10. - doi: 10.1016/j.biombioe.2011.01.020

Reed DD, Gren EJ (1984). Compatible stem taper and volume ratio equations. Forest Science 30 (4): 977-990.

Sierra CA, del Valle JI, Orrego SA, Mareno FH, Harmon MA, Zapata M, Colorado GJ, Herrera MA, Lara W, Restrepo DE, Berroguet LM, Loaiza LM, Benjumea JF (2007). Total carbon stoks in a tropical forest landscape of the Porce region, Colombia. Forest Ecology and Management 243: 299-309. - doi: 10.1016/j.foreco.2007. 03.026

Singh V, Tewari A, Kushwaha SPS, Dadhwal VK (2011). Formulating allometric equations for estimating biomass and carbon stock in small diameter trees. Forest Ecology and Management 261: 1945-1949. - doi: 10.1016/j.foreco.2011. 02.019

Soares MLG, Schaeffer-Novelli Y (2005). Aboveground biomass of mangrove species. I. Analysis of models. Estuarine Coastal and Shelf Science 65: 1-18. - doi: 10.1016/j.ecss.2005.05.001

Somogyi Z, Teobaldelli M, Federici S, Matteucci G, Pagliari V, Grassi G, Seufert G (2008). Allometric biomass and carbon factors database. iForest 1: 107-113. - doi: 10.3832/ifor0463-0010 107

Specht A, West PW (2003). Estimation of biomass and sequestered carbon on farm forest plantations in northern West South Wales, Australia. Biomass Bioenergy 25: 363-379. - doi: 10.1016/S0961-9534(03)00050-3

UNFCCC (2001). COP final document (Marrakesh Accords). FCCC/CP/2001/13/Add.1-4. [online] URL: http://unfccc.int/resource/docs/ 2005/cmp1/eng/03a04.pdf

Yilmaz E, Gürses K (1997). Cedar in eastern mediterranean forestry. Journal of Eastern Mediterranean Forest Research Institute 3: 1-23.

Zewdie M, Olsson M, Wervijst T (2009). Aboveground biomass production and allometric relations of Eucalyptus globulus Labill. Coppice plantations along a chronosequence in the central highlands of Ethiopia. Biomass Bioenergy 33: 421-428. - doi: 10.1016/j.biombioe.2008.08.007 Zhang Q, Wang C, Wang X, Quan X (2009). Carbon concentration variability of 10 Chinese temperate tree species. Forest Ecology and Management 258: 722-727. - doi: 10.1016/j.foreco.2009. 05.009 